\title{
Composition of Extracellular Polymeric Substances (EPS) produced by Flavobacterium columnare isolated from tropical fish in Brazil
}

\author{
Fernanda de Alexandre Sebastião ${ }^{1}$, Fabiana Pilarski ${ }^{1,2}$, Manoel Victor Franco Lemos ${ }^{1}$ \\ ${ }^{1}$ Programa de Pós-Graduação em Microbiologia Aplicada à Agropecuária, \\ Universidade Estadual Paulista "Julio de Mesquita Filho", Jaboticabal, SP, Brazil. \\ ${ }^{2}$ Centro de Aqüicultura, Universidade Estadual Paulista "Julio de Mesquita Filho", \\ Jaboticabal, SP, Brazil.
}

Submitted: January 26, 2012; Approved: September 10, 2012.

\begin{abstract}
Thirty nine isolates of Flavobacterium columnare from Brazilian fish farms had their carbohydrate composition of EPS evaluated by high efficiency liquid chromatography, using the phenol-sulfuric acid method of EPS. The occurrence of capsules on $F$. columnare cells was not directly related to biofilm formation, and the predominant monosaccharide is glucose.
\end{abstract}

Key words: biofilm, extracellular polymeric substances, Flavobacterium columnare, fish.

Flavobacterium columnare, the bacterium responsible for columnaris, is a long, Gram-negative, non-flagellated rod that exhibits motility by gliding on solid surfaces. It growths under temperatures ranging from $4{ }^{\circ} \mathrm{C}$ to $35^{\circ} \mathrm{C}$, being $25^{\circ} \mathrm{C}$ the ideal temperature. It is considered an opportunistic bacterium that is part of the normal water and fish microbiota (Olivares-Fuster et al., 2007; Schneck and Caslake, 2006).

Columnaris stands out among diseases of bacterial etiology in intensive tilapia rearing systems (Figueiredo and Leal, 2006), causing substantial economical losses because there are no available vaccines. Further, Brazilian fishing regulation only allows pharmaceutical use in the preventive control of epizootics.

The genus Flavobacterium, which includes species such as $F$. columnare, $F$. psychrophilum, $F$. branchiophilum, $F$. aquatile, $F$. johnsoniae, $F$. hydatis, and $F$. succinicans, has been detected on the banks of fish rearing systems displaying biofilm formation and during epizootic outbreaks. These rearing systems provide an ideal habitat for biofilm formation due to rich nutrient flow, host proximity and ample surface varieties that are susceptible to bacterial colonization. However, data on the mechanism of adhesion are still scarce.

It is known that bacteria in biofilms produce extracellular polymeric substances (EPS), or carbohydrate poly- mers, which allow free-living bacteria to adhere and colonize solid surfaces where nutrients accumulate (Costerton et al., 1999). EPS surround cell membranes, protecting them from environmental stress, and due to the ionic nature of the capsules, they can help minerals and nutrients to accumulate near bacteria (Weiner et al., 1995).

The EPS contribute directly to the properties of biofims in that they normally permit considerable amounts of water to be bound. Polysaccharides such as hyaluronic acid can bind up to $1 \mathrm{~kg}$ water (Mayer et al., 1999).

Biofilm formation is not only an important stage in the pathogenicity of organisms, but its establishment in host tissue (biotic) or inanimate (abiotic) surfaces inhibits the effectiveness of antimicrobial therapies and provides protection against host defense mechanisms. Further, it facilitates communication among bacteria, to virulence expression, which creates an ecological niche for microorganisms to promote epizootics or recurrent infections in the aquaculture environment (Basson et al., 2007).

The EPS also contribute to the mechanical stability of the biofilms, enabling them to withstand considerable shear forces. But these may be very weak and consequently may be readily destroyed by shear or dissolution of the polysaccharides (Sutherland, 2001).

An alternative for disease control would be the development of polysaccharases or polysaccharide lyases meth-

Send correspondence to F. Pilarski. Centro de Aqüicultura, "Julio de Mesquita Filho", Rod. Paulo Donato Castellane s/n, Bairro Rural, Jaboticabal, SP, Brazil. E-mail: fabianap@caunesp.unesp.br. 
ods that would prevent biofilm formation at its early stages, thus preventing infection in fish. However, for this purpose the composition of polysaccharides that constitute the EPS of pathogenic bacteria should be investigated.

The objectives of this study were to evaluate the monosaccharide composition of crude EPS produced by $F$. columnare, compare them to the ones produced by $A$. hydrophilla using 1-phenyl-3-methyl-5-pyrazolone (PMP) as a chemical marker of monomers, and evaluate the relationship between capsule formation and EPS production.

This study used 39 isolates of Flavobacterium columnare obtained from a variety of columnaris infected fish species, including nile tilapia (Oreochromis niloticus), tambaqui (Colossoma macropomum) and matrinxã (Brycon amazonicus) from fish farms situated throughout the State of São Paulo (Brazil) during the period from 2008-2009.

The strains were biochemical and molecularly characterized by intraspecific variation of the 16S rDNA gene using the PCR-RFLP technique (Sebastião et al., 2010). Additionally, strains of Aeromonas hydrophila and Streptococcus agalactiae (Laboratory of Aquatic Organisms Pathology - Aquaculture Center of São Paulo State University (CAUNESP), Jaboticabal, SP, Brazil) were utilized as controls.

Capsule formation was detected by growing the bacterial strains in Congo Red Agar (CRA), as described by Freeman et al. (1989). Congo red indicates $\mathrm{pH}$ alterations, presenting a blackish color when the $\mathrm{pH}$ is between 3.0 and 5.2 .

All $F$. columnare, A. hydrophila, and $S$. agalactiae strains were placed in Petri dishes containing autoclaved CRA, which consisted of $0.8 \mathrm{~g}$ Congo Red dye, 1.0 L Brain Heart Infusion media (HIMEDIA Laboratories PVT. LTD, LBS Marg, India) and $50 \mathrm{~g}$ sucrose (Merck, Darmstadt, Germany). Bacteria were then incubated at $30^{\circ} \mathrm{C}$, for $24 \mathrm{~h}$, followed by another $48 \mathrm{~h}$ at room temperature for qualitative detection of biofilm formation.

Capsule production was indicated by the presence of blackish and rough colonies while its absence was indicated by red and smooth ones.

Among the 39 isolates of Flavobacterium columnare, $19(49 \%)$ presented a positive CRA result, while 20 (51\%) were negative for the assay (Table 1). Table 1 also shows that $31,5 \%$ of CRA positive and $35 \%$ of CRA negative $F$. columnare isolates presented carbohydrate in EPS composition. The control strains Aeromonas hydrophila and Streptococcus agalactiae were both positive for the presence of capsule formation, but only the first were EPS positive.

Flavobacterium sp isolates have been identified in various biofilm structures, but the adherence mechanisms have not yet been elucidated. The absence of conventional structures associated with biofilm formation, such as fimbriae, pili, and flagella suggest that hydrophobic surfaces
Table 1 - Correlation between Flavobacterium columnare, Aeromonas hydrophila e Streptococcus agalactiae isolates by Congo Red Test and Extracellular Polymeric Substances (EPS) production.

\begin{tabular}{|c|c|c|c|c|}
\hline \multirow{2}{*}{$\begin{array}{l}\text { Strain } \\
F . \text { columnare }(\mathrm{n}=39)\end{array}$} & \multicolumn{2}{|c|}{ CRA } & \multicolumn{2}{|c|}{ EPS } \\
\hline & + & $19(49 \%)$ & + & $\begin{array}{c}6 \\
(31.5 \%)\end{array}$ \\
\hline & + & $19(49 \%)$ & - & $\begin{array}{c}13 \\
(68.5 \%)\end{array}$ \\
\hline & - & $20(51 \%)$ & + & $7(35 \%)$ \\
\hline & - & $20(51 \%)$ & - & $13(65 \%)$ \\
\hline A. hydrophila (control) & + & & + & \\
\hline S. agalactiae (control) & + & & - & \\
\hline
\end{tabular}

and/or self-aggregation and co-aggregation may play an important role in adhesion and biofilm formation (Basson et al., 2007).

Furthermore, it is believed that adhesion to a substrate is related to the amount of constituent polysaccharides, such as lectin. It is probable that such polysaccharides, combined with adhesins, capsules, and a hydrophobic surface, play an integral role in allowing bacteria to attack a biotic or abiotic surface forming a biofilm (Møller et al., 2003).

The $S$. agalactiae strain was positive for capsule formation; however it was unable to grow in TSA (Trypticase Soy Agar) medium (Biolife, Milan, Italy), impeding EPS extraction for this strain.

Some studies with coagulase-positive Staphylococcus strains have reported that capsule production facilitates bacterial adhesion through its biopolymer components contributing to biofilm formation (Freeman et al., 1989; Peters and Pulverer, 1984). However, our data contradict this assertion, at least in respect to Flavobacterium columnare isolates, where biofilm formation was not directly related to capsule formation, and this is the first study that evaluates this parameter for $F$. columnare isolates.

To evaluate the monosaccharide composition of crude EPS, each $F$. columnare isolates and the control strain of $A$. hydrophila were seeded in ten Petri dishes with TSA and incubated for 10 days at $30^{\circ} \mathrm{C}$. After the incubation, cells were scraped and dissolved in $25 \mathrm{~mL}$ of $0.85 \%$ saline solution, gently homogenized for 30 to $40 \mathrm{~s}$, and centrifuged at 14,700 $\mathrm{g}$ for $40 \mathrm{~min}$ for pellet sedimentation.

The polysaccharides were then precipitated by adding three times the volume of cold $96 \%$ ethanol to the culture filtrate. The mixture was centrifuged at $14,700 \mathrm{~g}$ for $20 \mathrm{~min}$ at $4{ }^{\circ} \mathrm{C}$. The supernatant was discarded, and the pellet was dried at room temperature for 5 days.

The total carbohydrate content in the precipitated EPS was determined using the phenol-sulfuric acid method (Dubois et al., 1956), using glucose as a standard. Monosaccharide composition was determined by HPLC after $2 \mathrm{NH}_{2} \mathrm{SO}_{4}$ hydrolysis at $100{ }^{\circ} \mathrm{C}$ for $3 \mathrm{~h}$. 
After hydrolysis, the EPS and monosaccharide standards were pre-derivatized with PMP, a chemical marker. The reactions were conducted by adding $40 \mu \mathrm{L}$ of PMP solution $(0.5 \mathrm{~mol} / \mathrm{L}$ in methanol $)$ and $40 \mu \mathrm{L}$ of sodium hydroxide solution $(0.3 \mathrm{~mol} / \mathrm{L})$ to each tube. The tubes were agitated and incubated at $70{ }^{\circ} \mathrm{C}$ for $2 \mathrm{~h}$. The mixture was then neutralized by adding $40 \mu \mathrm{L}$ of hydrochloric acid solution $(0.3 \mathrm{~mol} / \mathrm{L})$ at to room temperature. For the extraction of monosaccharide derivatives, $0.5 \mathrm{~mL}$ of butyl ether was added, and the tubes were agitated for $5 \mathrm{~s}$. The layers were separated by centrifugation at 5,000 $\mathrm{g}$ for $5 \mathrm{~min}$, and the upper phase (organic layer) was then removed and discarded. This extraction process was repeated three times, and the resulting aqueous phase was mixed with $400 \mu \mathrm{L}$ of milli-Q water.

PMP-labeled monosaccharide analyses were performed in an HPLC system equipped with a UV/VIS (Shimadzu, model SPD-M10A) detector. The wavelength for detection was $245 \mathrm{~nm}$. Monosaccharide derivatives with PMP were separated using a GHRC ODS-C-18 (4.6 mm i.d. X $15 \mathrm{~cm}$ ) column with a constant $0.5 \mathrm{~mL} / \mathrm{min}$ flow using buffers A and B, which consist of $100 \mathrm{mmol} / \mathrm{L}$ ammonium acetate at $\mathrm{pH} 5.5$, with $10 \%$ and $25 \%$ acetonitrile, respectively. The gradient of separation was as follows: $0 \%$ of B, $30 \mathrm{~min}$ and $0 \%$ to $100 \%$ of B, up to $100 \mathrm{~min}$. The volume of the standard injected was $20 \mu \mathrm{L}$.

For sample quantification, a quantification curve was developed using D-glucose, mannose, D-galactose, galacturonic acid, and glucuronic acid (Castellane and Lemos, 2007).
The carbohydrate composition of EPS produced by $F$. columnare strains consisted predominantly of glucose and glucuronic acid, with traces of galactose, mannose, and rhamnose. A. hydrophila showed a predominance of rhamnose and uronic acids, with trace amounts of glucose, galactose, and mannose (Table 2).

The polysaccharides isolated from $F$. columnare and $A$. hydrophila bacterial culture filtrates were all heteropolysaccharides, with varying proportions of neutral sugars and uronic acids. Rhamnose was detected in all samples, and glucose was found in higher concentrations in $F$. columnare strains. These data corroborate previous work by Ratto et al. (2005) with Cytophaga species (former nomenclature of the genus Flavobacterium).

As previously reported by Castellane and Lemos (2007), a necessary step to generate these data is the need to slowly grow bacteria in Petri dishes to obtain the highest possible production of EPS. It is known that EPS have protective functions for the bacterial cell in stressful environmental conditions, and therefore, their expression in vitro is favored when the environment is poor in nutrients or when the temperature is not optimal for growth of the species in question.

However, the low amounts of monosaccharide extracted may be due to numerous factors, as reported by Ratto et al. (2005), such as difficulty in obtaining a culture medium that induces biofilm formation and at the same time contains the requirements for bacterial growth. Additionally, abiotic factors and impurities released by bacterial cells in the process of EPS extraction can contribute to low yield.

Table 2 - Composition of the monosaccharides of Extracellular Polymeric Substances produced by Flavobacterium columnare and Aeromonas hydrophila cultured in TSA for 10 days at $30^{\circ} \mathrm{C}$ and the Congo Red phenotype.

\begin{tabular}{|c|c|c|c|c|c|c|c|}
\hline Samples & $\begin{array}{l}\text { Congo red } \\
\text { phenotype }\end{array}$ & $\begin{array}{c}\text { Mannose } \\
(\mathrm{mg} / \mathrm{L})\end{array}$ & $\begin{array}{l}\text { Rhamnose } \\
\text { (mg/L) }\end{array}$ & $\begin{array}{l}\text { Glucuronic acid } \\
\qquad(\mathrm{mg} / \mathrm{L})\end{array}$ & $\begin{array}{l}\text { Galacturonic } \\
\text { acid }(\mathrm{mg} / \mathrm{L})\end{array}$ & $\begin{array}{c}\text { Glucose } \\
(\mathrm{mg} / \mathrm{L})\end{array}$ & $\begin{array}{c}\text { Galactose } \\
(\mathrm{mg} / \mathrm{L})\end{array}$ \\
\hline F7 & - & 0.005 & 0.003 & 0.011 & * & 0.006 & 0.006 \\
\hline F9 & + & 0.005 & 0.002 & 0.005 & $*$ & 0.001 & 0.024 \\
\hline F15 & + & 0.003 & 0.001 & 0.009 & * & 0.027 & 0.005 \\
\hline F16 & - & 0.009 & 0.002 & 0.016 & $*$ & 0.026 & 0.005 \\
\hline F19 & - & 0.006 & 0.003 & 0.016 & * & 0.017 & 0.005 \\
\hline F27 & + & 0.009 & 0.005 & 0.015 & * & 0.022 & 0.006 \\
\hline F29 & + & * & 0.006 & $*$ & 0.005 & $*$ & 0.001 \\
\hline F32 & - & 0.014 & 0.001 & 0.012 & $*$ & 0.005 & 0.008 \\
\hline F33 & - & 0.005 & 0.005 & 0.012 & $*$ & 0.002 & 0.007 \\
\hline F36 & + & 0.005 & 0.001 & 0.013 & * & 0.020 & 0.007 \\
\hline F41 & - & 0.006 & 0.004 & 0.019 & $*$ & 0.010 & 0.004 \\
\hline F43 & + & 0.002 & 0.022 & 0.028 & 0.007 & 0.005 & $*$ \\
\hline F48 & + & $*$ & 0.015 & 0.024 & 0.006 & * & 0.002 \\
\hline A & + & 0.002 & 0.014 & 0.006 & 0.005 & 0.004 & 0.001 \\
\hline
\end{tabular}

Flavobacterium columnare (referred as F7, F9, F15, F16, F19, F27, F29, F32, F33, F36, F41, F43, F48) and Aeromonas hydrophila (referred as A). TSA (Trypticase Soy Agar).

+: postive for capsule formation, -: negative for capsule formation. 
Knowing that microbial polysaccharides are integral biofilm components and its matrix varies widely depending on expressed cellular structures and prevailing conditions, an alternative to control epizootics is the development of polysaccharases and/or polysaccharide lyases as suitable enzymatic treatments for EPS destabilization.

Enzymatic methods based on proteinases are already in use in paper companies to reduce biofilm formation. Thus, protein structures have been demonstrated to be especially involved in the initial stages of biofilm development, and the initial connection is usually stabilized by polysaccharides in mature biofilms (Ratto et al., 2005). In the future, similar enzymatic methods should be developed for similar application in pisciculture as a preventive measure to disease outbreak.

Furthermore, knowledge of the monosaccharides present in $F$. columnare and A. hydrophila EPS is relevant data for future studies to use enzymatic methods for the control and/or prevention of adhesion and biofilm formation of these pathogens. Such methods could prevent epizootics, which not only present a health problem but also cause substantial economical losses in aquaculture worldwide.

\section{Acknowledgments}

We thank Dr Eliana Gertrudes de Macedo Lemos and Dr Tereza Cristina Luque Castellane for their assistance with the EPS production experiment.

\section{References}

Basson A, Flemming LA, Chenia HY (2007) Evaluation of adherence, hydrophobicity, aggregation, and biofilm development of Flavobacterium johnsoniae-like isolates. Microbial Ecol 55:1-14.

Castellane TCL, Lemos EGM (2007) Composição de exopolissacarídeos produzidos por estirpes de rizóbios cultivados em diferentes fontes de carbono. Pesq Agrop Bras 42:15031506.
Costerton JW, Stewart PS, Greenberg EP (1999) Bacterial biofilms: A common cause of persistent infections. Science 284:1318-1322.

Dubois M, Gilles KA, Hamilton JK, Rebers PA, Smith F (1956) Colorimetric method for determination of sugars and related substances. J Anal Chem 28:350-356.

Figueiredo HS, Leal CAG (2008) Tecnologias aplicadas em sanidade de peixes. R Bras Zootec 37:08-14.

Freeman DJ, Falkiner FR, Keane CT (1989) New method for detecting slime production by coagulase negative staphylococci. J Clin Pathol 42:872-874.

Mayer C, Moritz R, Kirschner C, Borchard W, Maibaum R, Wingender J, Flemming HC (1999) The role of intermolecular interactions: studies on model systems for bacterial biofilms. Int J Biol Macromol 26:3-16.

Møller JD, Larsen JL, Madsen L, Dalsgaard I (2003) Involvement of a sialic acid-binding lectin with hemagglutination and hydrophobicity of Flavobacterium psychrophilum. Appl Environ Microbiol 69:5275-5280.

Olivares-Fuster O, Shoemaker CA, Klesius PH, Arias CR (2007) Molecular typing of isolates of fish pathogen, Flavobacterium columnare, by single-strand conformation polymorphism analysis, FEMS Microbiol Lett 269:63-69.

Peters G, Pulverer G (1984) Pathogenesis and management of Staphylococcus epidermidis 'plastic' foreign body infections. J Antimicrob Chemother supplement D:67-71.

Ratto M, Suihko M-L, Siika-Aho M (2005) Polysaccharideproducing bacteria isolated from paper machine slime deposits. J Ind Microbiol Biotechnol 32:109-114.

Sebastião FA, Pilarski F, Lemos MVF (2010) Isolation and molecular characterization of Flavobacterium columnare strains from fish in Brazil. J Bacteriol Res 3:22-29.

Schneck JL, Caslake LF (2006) Genetic diversity of Flavobacterium columnare isolated from fish collected from warm and cold water. J Fish Dis 29:245-248.

Sutherland IW (2001) Biofilm exopolysaccharides: a strong and sticky framework. Microbiol 147:3-9.

Weiner R, Langille S, Quintero E (1995) Structure, function and immunochemistry of bacterial exopolysaccharides. J Ind Microbiol 15:339-346.

All the content of the journal, except where otherwise noted, is licensed under a Creative Commons License CC BY-NC. 